\title{
N, P and K Fertilizers Alter Plant Growth, Essential Oil Yield and Gender of Sweet Gale (Myrica gale L)
}

\author{
Xianmin Chang ${ }^{1, *}$ and Peter Martin ${ }^{2}$
}

\author{
${ }^{1}$ School of Agriculture, Food and Environment, Royal Agricultural University, Cirencester, GL7 6JS, UK; ${ }^{2}$ Agronomy \\ Institute, Orkney College, University of the Highlands and Islands, East Road, Kirkwall, Orkney KW15 1 LX, UK
}

\begin{abstract}
To investigate whether the fertilizers N, P or K individually affect plant growth, oil content and the gender of sweet gale, two trials, pot and field trials, were carried out at Orkney College UHI in Scotland. A pot trial was established with eight soils which were collected from different sweet gale trial sites in the north of Scotland. Although neither shoot yield nor oil concentration in shoots was affected by soil, there were significant differences in shoot yields as a result of fertilizer treatments (nitrogen $(\mathrm{N})$, phosphorus $(\mathrm{P})$, potassium $(\mathrm{K})$ or none (control)). The best yield was obtained from the $\mathrm{N}$ treatment which was double to that of the control and P treatments. N, P or K fertilizers did not consistently affect shoot oil concentration in two seasons; however, oil yield was significantly affected, and $\mathrm{N}$ treatment produced two-three fold oil yield increases compared with the control or P treatment. In the $\mathrm{N}$ treatment, the increase in shoot yield was positively correlated with total nitrogen or nitrate nitrogen in the soil, suggesting the occurrence of a nitrogen priming effect. Data suggested that as shoot yield increased the oil concentration in shoots decreased. Neither soil nor N, P or K fertilizers had a significant effect on oil composition. Amongst fertilizer treatments, P resulted in the largest number of plants changing gender from female to male. A field $\mathrm{N}$ trial confirmed that nitrogen significantly enhanced the shoot yield of young plants.
\end{abstract}

Keywords: Essential Oil, gender, growth, Myrica gale, NPK.

\section{INTRODUCTION}

The genus Myrica includes about 60 species and has a worldwide distribution. The word Myrica is derived from Greek, myron, meaning perfume [1,2]. Sweet gale (Myrica gale L.) is native to north-west Europe, North America and Asia [2]. It was reported that European M. gale populations are hexaploid while North American ones are dodecaploid [3]. Sweet gale is found throughout the UK except the Channel Isles and Shetland. Its use in brewing started about 2000 years ago in northern Holland, a practice which has been spread to many other places $[1,4]$. It is still used for flavouring of spirit today. It has been used as an insect repellent (antifeedant) for centuries, particularly for midges [1, 2, 5-7]. The leaves of $M$. gale are dried to perfume linen. The catkins or cones are boiled in water to produce scum beeswax for making candles. The roots and barks are used to tan calfskins or dye wool if collected in autumn. Dried nuts are used as a spice. The leaves are also used as stomachic and cordial medicines in China and for the treatment of dermal disease and dysentery in France [1]. Recent research suggests that the volatile oil has unique anti-bacterial effects and is highly resistant to oxidation [7,8], and has anticancer activity [9].

In Scotland, M. gale flowers from March to May on the wood of the previous year's growth, before the leaves are produced. The scented flowers are dioecious (individual flowers are either male or female, but only one sex is to be

*Address correspondence to this author at the School of Agriculture, Food and Environment, Royal Agricultural University, Cirencester, GL7 6JS, UK; Tel: +44 (0) 1285 652531; Fax: +44 (0) 1285 650219;

E-mail: changxianmin2002@yahoo.co.uk found on any one plant so both male and female plants must be grown if seed is required). Yellow-green or short red catkins appear in leaf axils in early summer, pollination is by the wind, and the plants are not self-fertile [1]. The staminate flowers are developed much earlier than pistillate catkins. This plant is occasionally monoecious and can also change sex from year to year, possibly as a result of nutrition [10], although this has not been investigated.

M. gale is able to obtain all its Nitrogen by $\mathrm{N}_{2}$-fixation and grows vigorously in $\mathrm{N}$-free nutrient solutions [11]. It also can take up $\mathrm{P}$ from wet, poor soil where $\mathrm{N}$ and $\mathrm{P}$ may be deficient by cluster roots which consist of dense clusters of determinate rootlets [1]. Root nodules can fix Nitrogen and this can have a significant impact on the communities on which it occurs [1] and can increase forest productivity on peat soils [12]. However, Camp [13] reported that although nutrient availability in good fen peat soils is sufficient for seedling establishment, plant growth is still enhanced by supplementary nutrients suggesting that the nutrient level in the wild fen peat is not optimal for M. gale growth. As a part of a project to investigate the potential for growing $M$. gale as an agricultural crop, the trials in this paper were established to investigate whether the fertilizers $\mathrm{N}, \mathrm{P}$ or K individually affect plant growth, oil content and the gender of $M$. gale.

\section{EXPERIMENTAL}

There were two trials, a pot trial and a field trial which were carried out by the Agronomy Institute at Orkney College UHI in Kirkwall, Scotland (N58 $58^{\prime}$ W02 $59^{\prime}$ ). The field trial was established to verify the pot trial results. 


\subsection{Pot Trial}

Eight different soils were collected from sweet gale planting sites in the north of Scotland (Table 1).

There were eight pots of each soil which were planted (one plant per pot) on 15 July 2008 (18 cm diameter pots, 4 litres) and re-potted in $25 \mathrm{~cm}$ diameter pots (8 litres) on 8 March 2010. Plants were three year old seedlings obtained from Alba Trees Ltd, UK. Plants were maintained in an open-ended polythene tunnel for five months and then moved outside in January 2009. Each plant pot was placed in its own saucer and from April to September plants were watered regularly to ensure that water was present in the saucer.

On 21 July 2008, plant height and stem diameter were measured to check the uniformity of plants before applying fertilizer treatments. The measurements showed that there were no significant differences in plant height (mean, $46.8 \mathrm{~cm}$; cv, $7.5 \%$ ), and stem diameter measured at $5 \mathrm{~cm}$ above the soil (mean $6.2 \mathrm{~mm}$; cv, 14.6\%).

\subsection{Fertilizer Treatment}

There were four fertilizer treatments applied to this trial, i.e. control (no fertilizer), N, P and K (Table 2). For each soil, there were two pots with each treatment. Therefore, there were sixteen pots for each fertilizer treatment and 64 pots in total. The amount of fertilizer applied per pot was based on a plant density at 40,000 plants per hectare. After fertilizer application, pots were completely randomized as $8 \times 8$ rows.

Fertilizer applications were made on 27 August 2008, 20 April 2009, 24 August 2009, 6 April 2010 and 7 June 2010.

\subsection{Plant Cutting Back and Harvesting}

Plants were cut back to $30 \mathrm{~cm}$ on 20 April 2009 before leaf emergence and harvested at $32 \mathrm{~cm}$ above the soil on 11 August 2009 and 12 August 2010. Therefore the harvesting did not include woody stems from the previous year's growth. At harvesting, the fresh weight of shoots per plant was recorded, and a mixed fresh shoot sample of two plants

Table 1. Characteristics of soils from eight sweet gale trial sites in Scotland used in the pot trial.

\begin{tabular}{|c|c|c|c|c|c|c|c|c|}
\hline Characteristic* & $\begin{array}{c}\text { Alvie } \\
\text { N57 }^{\circ} 09^{\prime} \\
\mathbf{W 0 3}^{\circ} 53^{\prime}\end{array}$ & $\begin{array}{l}\text { Black Isle } \\
\text { N57³8} \\
\text { W04 }^{\circ} 04^{\prime}\end{array}$ & $\begin{array}{c}\text { Blair Atholl } \\
\text { N56 }^{\circ} 46^{\prime} \\
\text { W03 }^{\circ} 56^{\prime}\end{array}$ & $\begin{array}{c}\text { Craibstone } \\
\text { N57 }{ }^{\circ} 11^{\prime} \\
\mathrm{W02}^{\circ} 13\end{array}$ & $\begin{array}{c}\text { Elgin } \\
\mathrm{N}^{\circ} 7^{\circ} 35 \\
\mathrm{~W}^{\circ} 3^{\circ} 21^{\prime}\end{array}$ & $\begin{array}{c}\text { Glen- } \\
\text { borrodale } \\
\text { N56 }^{\circ} 41^{\prime} \\
\text { W05 }^{\circ} 45\end{array}$ & $\begin{array}{l}\text { Kirkton } \\
\text { N56 }^{\circ} 25^{\prime} \\
\text { W04 }^{\circ} 39^{\prime}\end{array}$ & $\begin{array}{c}\text { Kirkwall } \\
\text { Orkney } \\
\text { N58 }^{\circ} 58^{\prime} \\
\text { W02 }^{\circ} 59^{\prime}\end{array}$ \\
\hline $\mathrm{pH}$ & 4.7 & 5.2 & 6.8 & 5.3 & 5.2 & 4.3 & 4.9 & 5.2 \\
\hline $\mathrm{P}\left(\mathrm{mg} \mathrm{l}^{-1}\right)$ & 8.40 & 31.70 & 13.50 & 62.90 & 25.30 & 11.30 & 45.20 & 37.40 \\
\hline $\mathrm{K}\left(\mathrm{mg} \mathrm{l}^{-1}\right)$ & 35.00 & 136.00 & 68.00 & 75.00 & 35.00 & 72.00 & 69.00 & 42.00 \\
\hline $\operatorname{Mg}\left(\mathrm{mg}^{-1}\right)$ & 29.00 & 100.00 & 21.00 & 117.00 & 34.00 & 59.00 & 55.00 & 93.00 \\
\hline Nitrate $\mathrm{N}\left(\mathrm{mg} \mathrm{kg}^{-1}\right)$ & 0.50 & 1.90 & 2.16 & 6.94 & 2.99 & 1.91 & 4.88 & 9.91 \\
\hline Ammonium N (mg kg $\left.{ }^{-1}\right)$ & 1.42 & 2.68 & 2.59 & 1.61 & 1.21 & 3.75 & 1.87 & 1.21 \\
\hline Available $\mathrm{N}\left(\mathrm{kg} \mathrm{ha}^{-1}\right)$ & 7.65 & 18.25 & 18.95 & 34.20 & 16.80 & 22.60 & 27.05 & 44.45 \\
\hline Total $\mathrm{N}\left(\% \mathrm{w} \mathrm{w}^{-1}\right)$ & 0.16 & 0.25 & 0.32 & 0.33 & 0.16 & 0.39 & 0.37 & 0.36 \\
\hline Sand $\%$ & 53.00 & 53.00 & 51.00 & 55.00 & 56.00 & 80.00 & 68.00 & 47.00 \\
\hline Silt \% & 37.00 & 37.00 & 34.00 & 30.00 & 32.00 & 16.00 & 26.00 & 38.00 \\
\hline Clay $\%$ & 10.00 & 10.00 & 15.00 & 15.00 & 12.00 & 4.00 & 6.00 & 15.00 \\
\hline Texture & Sandy Loam & Sandy Loam & Sandy Loam & Sandy Loam & Sandy Loam & Loamy Sand & Sandy Loam & $\begin{array}{l}\text { Sandy Silt } \\
\text { Loam }\end{array}$ \\
\hline
\end{tabular}

*The soils were analysed by NMR Ltd.

Table 2. Fertilizers and doses of each application.

\begin{tabular}{|c|c|c|c|c|}
\hline Fertilizer & $\begin{array}{c}\text { NPK } \\
\text { Composition }\end{array}$ & N,P or K $\left(\mathbf{k g ~ h a}^{-1}\right)$ & $\begin{array}{c}\text { Fertilizer } \\
\left(\mathbf{k g ~ h a}^{-1}\right)\end{array}$ & $\begin{array}{c}\text { Fertilizer } \\
\left(\mathbf{g ~ p o t}^{-1}\right)\end{array}$ \\
\hline \hline Control & N/A & N/A $/ A$ & N/A \\
\hline Sulphate of Ammonia & $20-0-0$ & 25 & 125.00 & 3.13 \\
\hline Superphosphate & $0-17-0$ & 25 & 147.00 & 3.63 \\
\hline Sulphate of Potash & $0-0-48$ & 25 & 52.10 & 1.30 \\
\hline
\end{tabular}


from the same treatment was collected for oil concentration and composition analysis.

\subsection{Field Nitrogen Trial}

To determine whether field-grown plants responded to $\mathrm{N}$, a field nitrogen trial was established. Planting was carried out on 9 March 2009 at Muddisdale (Agronomy Institute Field), Kirkwall in Orkney and used plants of two heights, i.e. 7-9 cm (from BritishFlora, UK) and 20-40 cm (from Quercus Garden Plants Ltd, UK) which are referred to as P1 and P2, respectively. Plant spacing was $50 \mathrm{~cm}$ by $50 \mathrm{~cm}$. Plot size was $2 \mathrm{~m}$ by $2.5 \mathrm{~m}$ with 20 plants per plot. All plants were cut back at $20 \mathrm{~cm}$ above the ground in March 2010 to standardise their canopy height. Kerb flo (3.75 $\mathrm{Lha}^{-1}$ ) and Roundup $360\left(1.9 \mathrm{Lha}^{-1}\right)$ were applied on 8 February 2010 for weed control.

There were three nitrogen treatments: i.e. N0, N30 and $\mathrm{N} 60$ (0, 30 and $60 \mathrm{~kg} \mathrm{~N} / \mathrm{ha}$, respectively) and the application was split so that half was applied on 7 April and half on 14 June 2010. Sulphate of ammonia (NPK 20:0:0) was used for this trial. A split plot field design was used with five replicates; the main plot was nitrogen treatment and subplot was plant materials. Plants were harvested on 12 August 2010. At harvesting, shoot yield per plot was measured and a $100 \mathrm{~g}$ per plot fresh shoot sample of the P2 plant material was collected for oil concentration and composition analysis.

\subsection{Oil Extraction and Analysis}

Samples for oil analysis were put in plastic bags, stored in a cool box $\left(\mathrm{ca} 10^{\circ} \mathrm{C}\right)$ then delivered to Inverness College UHI for analysis where all samples were immediately logged, given a sample number and then frozen at ca $-20{ }^{\circ} \mathrm{C}$ prior to analysis. Samples were prepared for distillation by roughly crushing the leaves whilst in the bag to break them up. This was then emptied into a clean tray. Large stalks and unbroken leaves were cut up into smaller pieces. The sample was then transferred to a round bottomed distillation flask and the weight recorded to two decimal places and $450 \mathrm{ml}$ of distilled water was added. Where samples were $50 \mathrm{~g}$ or less, $350 \mathrm{ml}$ was added.

The flask was placed onto a heating mantle and connected to the distillation apparatus for one hr distillation. The heater was then switched off and the sample allowed to settle for a few minutes. The water level was slowly lowered by opening the tap on the collection arm until the oil collected could be measured against the graduation marks. The water was then run off slowly and the oil collected in a dark glass vial, labeled and measured.

The quantity of collected oil was converted to oil concentration $\left(\mathrm{mll} 100 \mathrm{~g}^{-1}\right)$. Oil yield plant ${ }^{-1}$ was calculated for each treatment as the product of shoot yield plant ${ }^{-1}$ and oil concentration.

Oil samples were stored at ca $4{ }^{\circ} \mathrm{C}$ prior to analysis (normally within two days). $10 \mathrm{ul}$ of oil was transferred by micropipette to another dark glass vial and diluted with $490 \mathrm{ul}$ of ethyl acetate. The sample was then analysed by GC/MS (Hewlett Packard 5972 Mass Spectrometer with HP 5890 Series IIe Gas Chromatograph). Extracts were run on a $30 \mathrm{~m}$ x $0.25 \mathrm{~mm}$ ZB1 $0.25 \mu \mathrm{m}$ film column, mass spectra were obtained in EI mode $(70 \mathrm{eV})$ and scanning was from 35 - 500 amu. The injector and transfer line were kept at $250{ }^{\circ} \mathrm{C}$ and $280{ }^{\circ} \mathrm{C}$ respectively. The oven temperature was programmed from $60{ }^{\circ} \mathrm{C}$ to $246{ }^{\circ} \mathrm{C}$ at $3{ }^{\circ} \mathrm{C}$ per minute, held initially at $60{ }^{\circ} \mathrm{C}$ for two minutes, then ramped to $246{ }^{\circ} \mathrm{C}$ where it was held for 10 minutes. Helium carrier gas was used at $1.02 \mathrm{ml} \mathrm{min}^{-1}$, injection volume was $1.0 \mu 1$.

Five standard solutions $\left(0.1 \mathrm{mg} \mathrm{ml}^{-1}-0.8 \mathrm{mg} \mathrm{ml}^{-1}\right.$ pinene, phellandrene, para cymene, 1,8-cineole, limonene) were used to generate standard lines and to check the linear range. For identification of peaks other than the five standard compounds, Adams (2001) was adopted and his spectra and retention times were used as references.

\subsection{Statistical Analysis}

An analysis of variance (ANOVA) table was calculated for shoot yield and oil content. Differences between treatments were assessed using the F-test, and the Least Significant Difference (LSD) was calculated at the 0.05 probability level.

\section{RESULTS}

\subsection{Pot Studies}

In the pot trial, neither shoot yield nor oil yield were significantly affected by different soils in 2009 or 2010 (Table 3). Averaged over soils, there was however a significant $(\mathrm{P}<0.01)$ negative correlation between shoot yield and oil concentration which reduced the oil yield of plants with high shoot yields (Fig. 1).

Shoot yield plant ${ }^{-1}$ was significantly affected by fertilizer in both 2009 and 2010. The highest yield was obtained from the $\mathrm{N}$ treatment and it was about twice that of the control or $P$ treatment. Although the shoot yields of the control and $\mathrm{P}$ treatment were not significantly different, the $\mathrm{P}$ treatment had slightly lower shoot yields in both years.

Oil content was significantly affected by the fertilizer treatment in 2009 but not in 2010 . However, oil yield plant ${ }^{-1}$ was significantly affected by fertilizer in both years (Table 4), and the $\mathrm{N}$ treatment produced a two to three fold increase in oil yield plant ${ }^{-1}$ compared with the control or $\mathrm{P}$ treatment. As a result of having the lowest shoot yield and oil content, the $\mathrm{P}$ treatment produced the lowest oil yield, particularly in 2009 when this was significantly different to any other treatment.

In both years, linear regression analysis showed that the shoot yield in the nitrogen treatment was always significantly correlated $(\mathrm{P}<0.001)$ with soil available nitrogen or soil nitrate nitrogen content and, the regression lines accounted for $66 \%$ (Fig. 2) and 65\% (Fig. 3), respectively, of the variations in shoot yield. There were no other significant correlations between yield and soil characteristics.

Although there was no significant interaction between fertilizer and soil on shoot yield plant ${ }^{-1}(\mathrm{P}=0.990)$ or oil yield plant $^{-1}(\mathrm{P}=0.994)$ in 2009 , interactions were significant in 2010 for both shoot yield (Fig. 4) and oil yield (Fig. 5).

For most soils, the highest yields were with the $\mathrm{N}$ treatment but for Alvie soil the control treatment did slightly 
Table 3. Comparison of shoot and oil yields per plant in eight soils.

\begin{tabular}{|c|c|c|c|c|c|c|c|c|c|c|c|}
\hline Yield & Year & Alvie & $\begin{array}{l}\text { Black } \\
\text { Isle }\end{array}$ & $\begin{array}{c}\text { Blair } \\
\text { Atholl }\end{array}$ & $\begin{array}{l}\text { Craib- } \\
\text { stone }\end{array}$ & Elgin & $\begin{array}{c}\text { Glen- } \\
\text { borrodale }\end{array}$ & Kirkton & Orkney & SED & $\begin{array}{l}\text { Prob- } \\
\text { ability }\end{array}$ \\
\hline \multirow{2}{*}{$\begin{array}{l}\text { Shoot Yield } \\
\left(\text { g plant }^{-1}\right)\end{array}$} & 2009 & 22.1 & 18.9 & 32.8 & 25.6 & 30.0 & 19.6 & 23.0 & 21.1 & 8.820 & 0.722 \\
\hline & 2010 & 21.0 & 17.0 & 27.0 & 26.5 & 30.5 & 17.9 & 25.8 & 31.1 & 11.420 & 0.110 \\
\hline $\begin{array}{l}\text { Oil Yield } \\
\left(\mathrm{ml} \mathrm{plant}^{-1}\right)\end{array}$ & 2009 & 0.045 & 0.041 & 0.048 & 0.035 & 0.038 & 0.042 & 0.044 & 0.038 & 0.0160 & 0.994 \\
\hline
\end{tabular}

SED: Standard error of the difference.

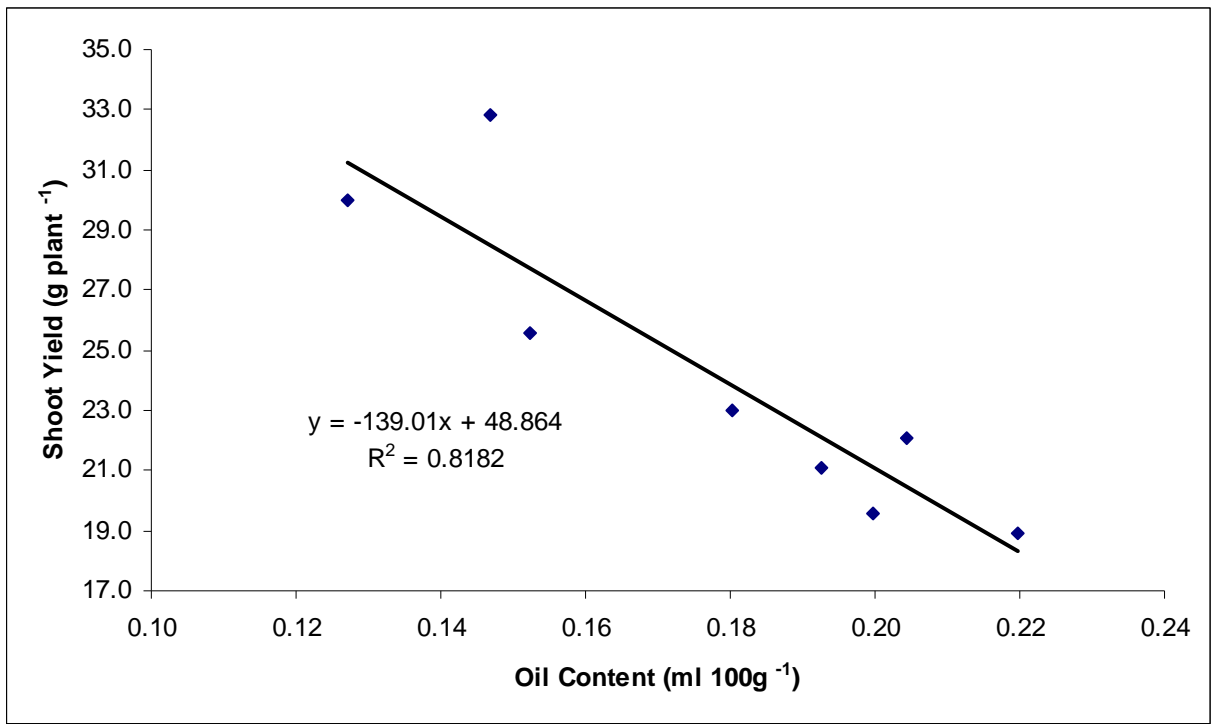

Fig. (1). Correlation between oil concentration and shoot yield (2009).

Table 4. Comparison of shoot and oil yields under different fertilizer treatments.

\begin{tabular}{|c|c|c|c|c|c|c|}
\hline \multirow{2}{*}{ Treatment } & \multicolumn{2}{|c|}{ Fresh Shoot Yield (g plant $\left.{ }^{-1}\right)$} & \multicolumn{2}{|c|}{ Oil Content (ml 100g $\left.\mathrm{g}^{-1}\right)$} & \multicolumn{2}{|c|}{ Oil Yield (ml plant ${ }^{-1}$ ) } \\
\hline & 2009 & 2010 & 2009 & 2010 & 2009 & 2010 \\
\hline $\mathrm{N}$ & 35.20 & 40.56 & 0.178 & 0.250 & 0.060 & 0.101 \\
\hline $\mathrm{P}$ & 19.70 & 17.75 & 0.146 & 0.200 & 0.027 & 0.035 \\
\hline SED & 4.28 & 3.96 & 0.017 & 0.047 & 0.001 & 0.008 \\
\hline Probability & 0.003 & $<0.001$ & 0.007 & 0.676 & 0.013 & $<0.001$ \\
\hline
\end{tabular}

SED: Standard error of the difference.

better than the $\mathrm{N}$ treatment. The highest yields were obtained from Orkney soil with $\mathrm{N}$ treatment which produced a shoot yield plant ${ }^{-1}$ and oil yield plant ${ }^{-1}$ of $77 \mathrm{~g}$ and $0.192 \mathrm{ml}$ respectively, whereas, the lowest shoot yields $\left(7 \mathrm{~g} \mathrm{plant}^{-1}\right)$ were obtained from Kirkton and Orkney soils with the $\mathrm{K}$ treatment, and Black Isle soil with the control or P treatment. The lowest oil yields were also obtained from the same soil and fertilizer treatments which produced 0.013-0.014 ml plant ${ }^{-1}$. Although in most soils, the $\mathrm{K}$ treatment reduced both shoot yield and oil yield, in Elgin and Craibstone soils this treatment enhanced yields com- pared with the control, and the shoot yield was even slightly higher than that of the $\mathrm{N}$ treatment.

\subsection{Field studies}

The field $\mathrm{N}$ trial confirmed the pot trial result and demonstrated that $\mathrm{N}$ increased shoot yield, particularly of the younger P1 material where the N60 treatment produced about a three fold increase compared with the control treatment. Although the effect on the older material was not significant, the trend was the same as for the younger material (Table 5). The N30 treatment slightly increased the oil 




Fig. (2). Correlation between soil available nitrogen and the shoot yield of two year average under nitrogen treatment.

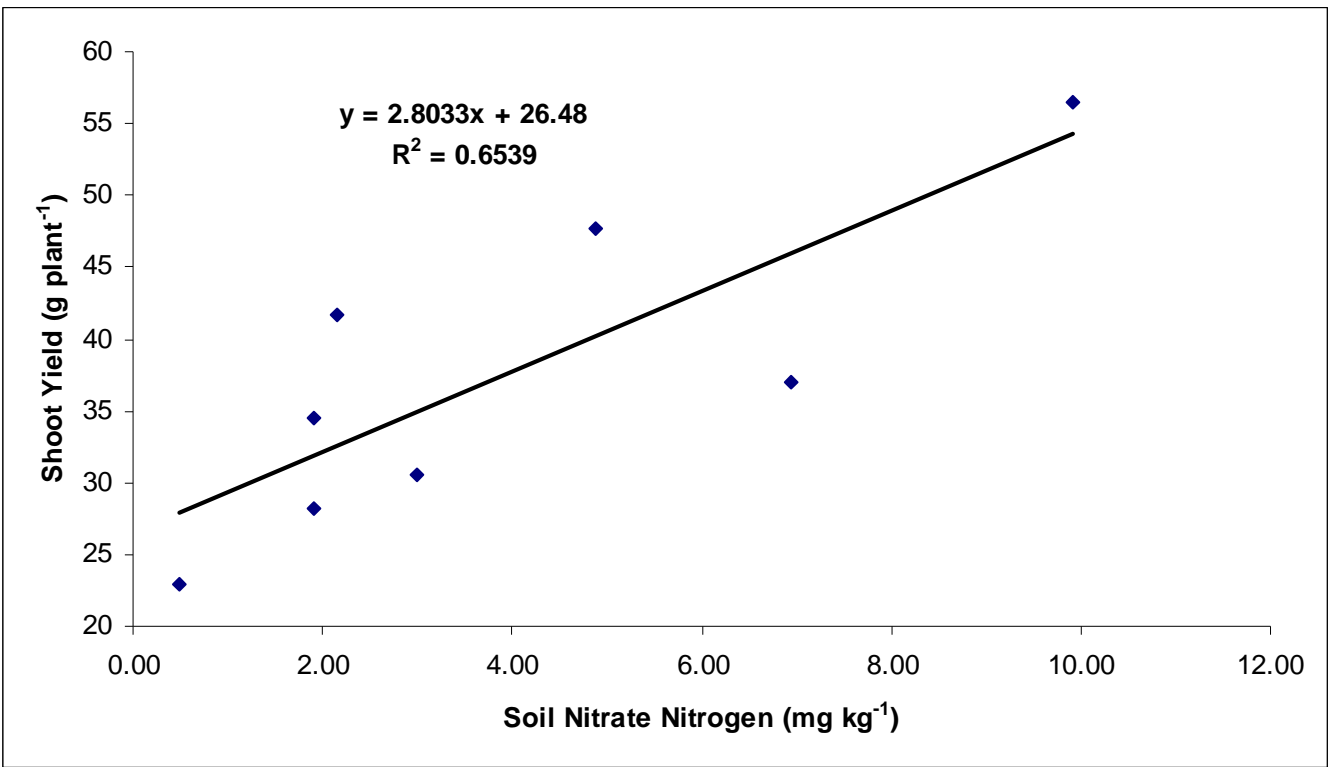

Fig. (3). Correlation between soil nitrate nitrogen and the shoot yield of two year average under nitrogen treatment.

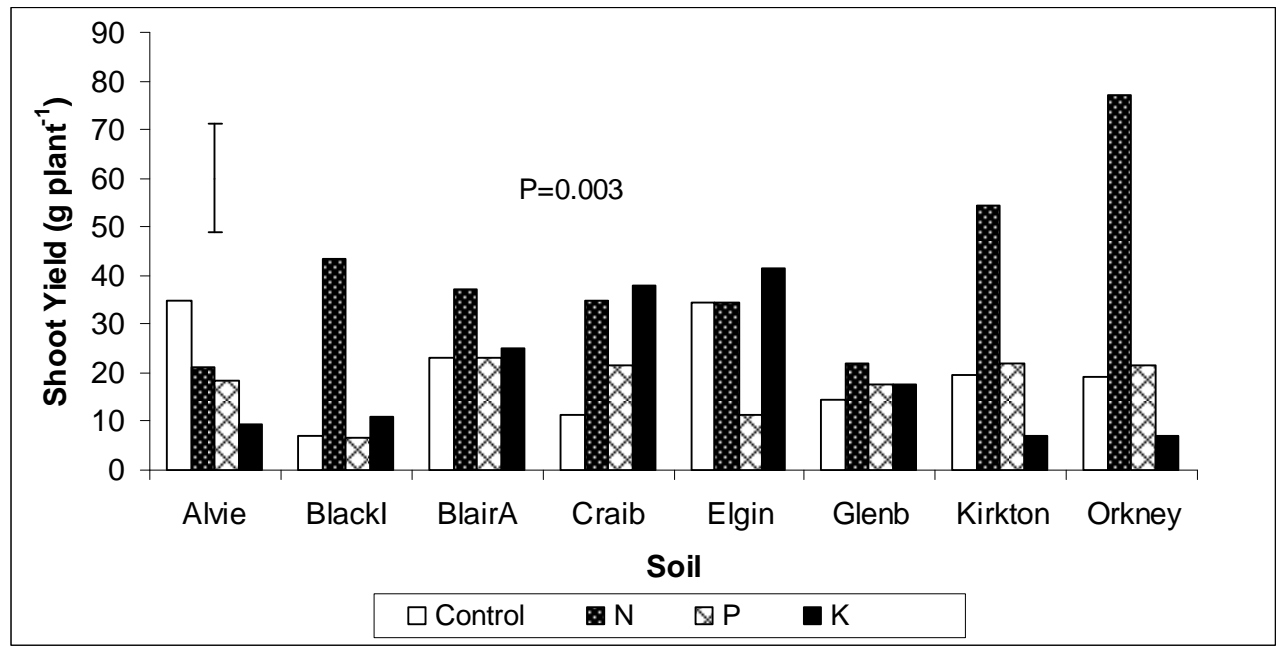

Fig. (4). Effect of soil and fertilizer treatments on shoot yield plant ${ }^{-1}$ in 2010. 


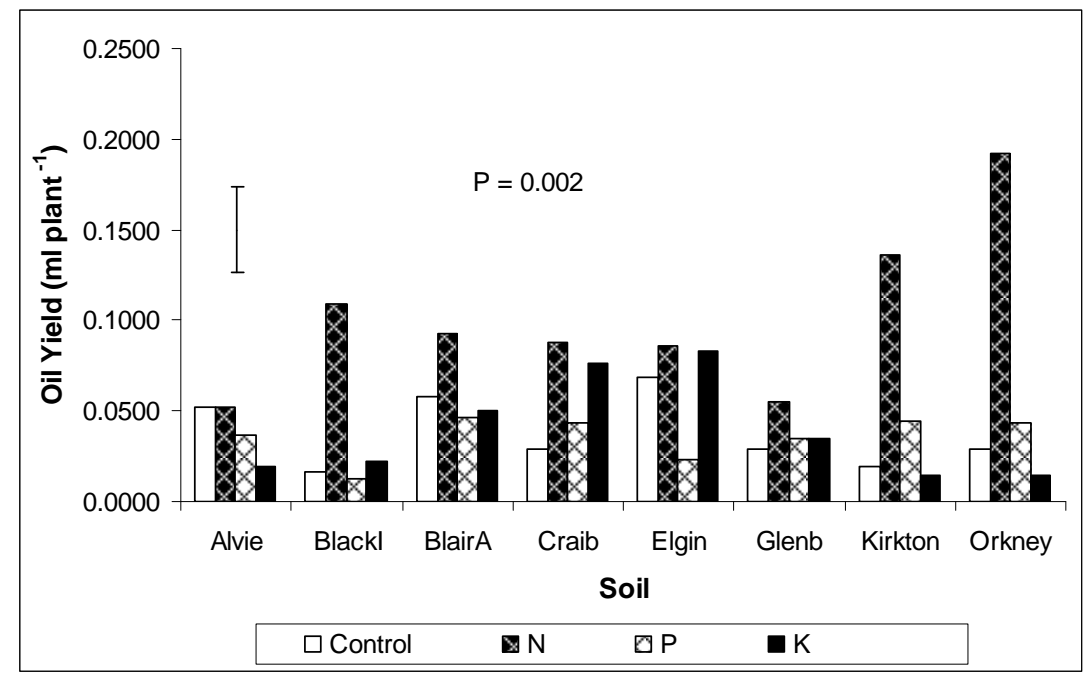

Fig. (5). Effect of soil and fertilizer treatments on oil yield plant ${ }^{-1}$ in 2010 .

Table 5. Shoot yield and oil concentration in the field under different $\mathbf{N}$ levels.

\begin{tabular}{|c|c|c|c|}
\hline Treatment & Shoot Yield of P1 (g plant $\left.{ }^{-1}\right)$ & Shoot Yield of P2 (g plant $)^{-1}$ & $\begin{array}{c}\text { Oil content of P2 } \\
\left(\mathbf{m l ~ 1 0 0 g}^{-1}\right)\end{array}$ \\
\hline \hline Control & 3.48 & 14.20 & 0.183 \\
\hline N30 & 5.71 & 15.50 & 0.233 \\
\hline N60 & 9.90 & 16.90 & 0.167 \\
\hline SED & 2.216 & 3.570 & 0.024 \\
\hline Probability & 0.039 & 0.770 & 0.068 \\
\hline
\end{tabular}

SED: Standard error of the difference.

content of the P2 material although this was not significantly different to that of the control. When nitrogen was increased to $60 \mathrm{~kg} \mathrm{ha}^{-1}$ the shoot yield of the older plants (P2) slightly increased but the oil content decreased.

Eleven major compounds were identified and analysed in both the pot and field trials. None of them was significantly affected by soil or fertilizer treatment in the pot trial in either 2009 or 2010 (Table 6). In the field trial, although only alpha pinene was significantly increased by nitrogen there were non-significant, but quite large, increases in beta pinene, myrcene and phellandrene (Table 7). In contrast, germacrene and nerolidol were decreased, but not significantly.

In 2009, all the fertilizer treatments in the pot trial had a lower proportion of male:female plants (Table 8). By 2011, the control, $\mathrm{K}$ and $\mathrm{N}$ treatments showed a slight increase in the proportion of male:female plants which resulted in a more balanced sex ratio. This was very much more marked in the $\mathrm{P}$ treatment, however, where four plants changed from female to male (Table 8). These were from Craibstone, Kirkton, Black Isle and Blair Atholl soils which, apart from the latter, already had relatively higher phosphorus content (Table 1).

\section{DISCUSSION}

This research suggested that Bog Myrtle can grow in agricultural soils with a range of characteristics, i.e. $\mathrm{pH}$ (4.3 -
6.8) in sandy loam and sandy silt loam soils (Table 1). Although the average shoot yields and oil yields of plants in the different soils were not significantly different, the response to the fertilizer treatments was different. Plants in Orkney soil were very responsive to $\mathrm{N}$ treatment whereas those in Alvie soil were not and most of those in the other soils were intermediate. It was also noticed that the shoot yield in the $\mathrm{N}$ treatment, but not in the control, was significantly correlated with soil available nitrogen or soil nitrate nitrogen. This may have resulted from a "nitrogen priming effect", interaction between fertilizer nitrogen and soil nitrogen [14], but needs further investigation.

Data from 2009 suggested that oil content decreased as shoot yield increased. This result agreed with previous field trial data suggesting a negative correlation between oil concentration and shoot yield per plant [15] due to dilution. Although oil content was not consistently affected by fertilizer treatment which was significant in 2009 but not in 2010, oil yield plant ${ }^{-1}$ was significantly affected by fertilizer treatments in both years, and $\mathrm{N}$ treatment in the pot trial produced two to three times the oil yield plant ${ }^{-1}$ of the control or $\mathrm{P}$ treatment. This result suggested that although sweet gale is able to obtain its nitrogen through $\mathrm{N}_{2}$-fixation and grows vigorously in $\mathrm{N}$-free nutrient solutions [11], supplementary nitrogen is still very important to enhance the yield of biomass as suggested by Camp [13]. The nitrogen field trial 
Table 6. Retention times (RT) and relative content (\%) of compounds identified in sweet gale shoot extracts from the pot trial in 2010.

\begin{tabular}{|c|c|c|c|c|c|c|c|}
\hline Alpha pinene & 6.070 & 19.05 & 19.10 & 17.61 & 18.19 & 3.051 & 0.942 \\
\hline Myrcene & 7.739 & 4.58 & 4.99 & 3.29 & 2.48 & 2.888 & 0.813 \\
\hline Para cymene & 8.700 & 3.74 & 3.55 & 3.67 & 3.45 & 1.144 & 0.990 \\
\hline 1,8 cineole & 8.950 & 17.11 & 16.08 & 16.50 & 19.20 & 2.777 & 0.766 \\
\hline Limonene & 9.040 & 10.81 & 10.41 & 9.88 & 9.37 & 1.704 & 0.939 \\
\hline Elemene G & 25.790 & 1.42 & 2.33 & 1.50 & 2.97 & 1.360 & 0.606 \\
\hline Germacrone & 34.880 & 13.74 & 7.68 & 10.21 & 3.42 & 8.180 & 0.541 \\
\hline
\end{tabular}

SED: Standard error of the difference.

Table 7. Retention times (RT) and relative content (\%) of compounds identified in sweet gale shoot extracts from the N field trial in 2010.

\begin{tabular}{|c|c|c|c|c|c|c|}
\hline Compound & RT & Control & N30 & N60 & SED & Probability \\
\hline Alpha pinene & 6.070 & 4.70 & 15.70 & 18.00 & 3.000 & 0.040 \\
\hline Beta Pinene & 7.260 & 0.99 & 2.40 & 2.68 & 0.541 & 0.098 \\
\hline Myrcene & 7.739 & 1.07 & 2.85 & 2.19 & 0.556 & 0.105 \\
\hline Phellandrene & 8.150 & 3.38 & 6.44 & 6.87 & 1.409 & 0.157 \\
\hline Para cymene & 8.700 & 1.64 & 2.53 & 3.00 & 0.685 & 0.278 \\
\hline 1,8 cineole & 8.950 & 9.50 & 12.00 & 17.50 & 3.370 & 0.198 \\
\hline Limonene & 9.040 & 5.05 & 8.16 & 9.13 & 1.563 & 0.154 \\
\hline Elemene G & 25.790 & 4.07 & 1.90 & 1.38 & 1.325 & 0.246 \\
\hline Germacrene & 30.380 & 23.40 & 11.00 & 8.60 & 7.510 & 0.254 \\
\hline Nerolidol & 30.690 & 12.70 & 9.00 & 6.20 & 3.650 & 0.334 \\
\hline Germacrone & 34.880 & 15.90 & 15.60 & 10.30 & 7.570 & 0.733 \\
\hline
\end{tabular}

SED: Standard error of the difference.

confirmed the pot trial result and also indicated that supplementary nitrogen was more effective on younger plants and may help early stage plant establishment. Results from water culture studies have shown that the form of $\mathrm{N}$ supply also affected the growth of sweet gale, and $\mathrm{NH}_{4}{ }^{+}$significantly enhanced the growth rate and shoot/root ratio, whereas, nitrate considerably reduced plant growth [16]. This needs further investigation in the field to confirm or otherwise. In contrast to the positive effect of $\mathrm{N}$, the pot trial showed that the P treatment had the lowest shoot and oil content which resulted in the lowest oil yield.
In this research, the major oil compounds were alpha pinene, phellandrene, 1,8 cineole, limonene, germacrene and germacrone which is very different to the findings of Svoboda et al. [2], who reported the variation in chemical composition of the volatile oil of $M$. gale from various geographical sources, (i.e. Scotland, Finland, Eastern USA, Canada Ontario, Netherlands and Spain). They suggested that the major compounds in Scottish oil were alpha pinene, 1,8 cineole, beta elemonene and germacrene, there was no trace of phellandrene and germacrone identified and the level of limonene was very low ( $1.5 \%$ of the relative content). 
Table 8. Number and percentage of plants of different gender in each fertilizer treatment from 2009 to 2011.

\begin{tabular}{|c|c|c|c|c|}
\hline \multirow{3}{*}{ CK } & Male & $6(37.5 \%)$ & $7(43.8 \%)$ & $7(43.8 \%)$ \\
\hline & Male:Female & 0.75 & 0.88 & 1.00 \\
\hline & Bisexual & 1 & 1 & $2(12.4 \%)$ \\
\hline \multirow[b]{3}{*}{ K } & Male & $6(37.5 \%)$ & $6(37.5 \%)$ & $6(37.5 \%)$ \\
\hline & Female & $9(56.3 \%)$ & $8(50.0 \%)$ & $7(43.8 \%)$ \\
\hline & Male:Female & 0.67 & 0.75 & 0.86 \\
\hline \multirow{4}{*}{$\mathrm{N}$} & Female & $8(50.0 \%)$ & $8(50.0 \%)$ & $8(50.0 \%)$ \\
\hline & Male:Female & 0.75 & 0.88 & 0.88 \\
\hline & Bisexual & 0 & 1 & $1(6.2 \%)$ \\
\hline & Not-known & 2 & 0 & 0 \\
\hline \multirow[b]{3}{*}{$\mathrm{P}$} & Male & $5(31.3 \%)$ & $9(56.3 \%)$ & $10(62.5 \%)$ \\
\hline & Female & $10(62.5 \%)$ & $6(37.5 \%)$ & $6(37.5 \%)$ \\
\hline & Male:Female & 0.5 & 1.50 & 1.70 \\
\hline
\end{tabular}

Svoboda et al. [2], suggested that the oil composition differed markedly from one country to another. Differences between our results and those of Svoboda et al. [2] suggest that further research would be useful to document the oil composition in different locations in Scotland as the previous authors' sample was collected from Inchmarnock $\left(55^{\circ} 47^{\prime} \mathrm{N}\right.$; $\left.50^{\circ} 11^{\prime} \mathrm{W}\right)$, the latitude of which is about $350 \mathrm{~km}$ south of that of Orkney where the present research was conducted. Compared with the distillation methods used by Svoboda et al. [2], those in current research were different. In terms of the length of distillation, the previous research used $2 \mathrm{hr}$ distillation while $1 \mathrm{hr}$ distillation was used for the current research. This would make a significant difference as Sylvestre et al. [9], suggested that the length of distillation significantly affected the oil composition. Furthermore, the previous research used dried leaves for oil extraction and the current research used fresh leaves which could also make another significant difference.

Davey and Gibson [10] suggested that M. gale plant could change sex from year to year and this might be caused by nutrition, however, no further investigation of this has been done since then. Although this research observed that there were more $M$. gale plants altered from female to male in the phosphorus treatment, no definite conclusion could be drawn. This however may draw attention to scientists for in depth investigation with field trials and in the wild to compare the content of nutrition in the soils and the sex ratios of populations, and then to understand the mechanism of the alteration.

The results of this research suggest that nitrogen fertilizer could be used to increase the shoot and oil yields of sweet gale grown on agricultural land, although the effect of this on the chemical composition of the oil needs further investigation.

\section{CONFLICT OF INTEREST}

The authors confirm that this article content has no conflict of interest.

\section{ACKNOWLEDGEMENTS}

The authors would like to thank the Boots Company, Highlands and Islands Enterprise, Highland Natural Products and Essentially Scottish Botanicals for support with this research project.

\section{REFERENCES}

[1] Skene KR, Sprent JI, Raven JA, Herdman L. Biological flora of the British Isles - Myrica gale L. J Ecol 2000; 88: 1079-94. 
[2] Svoboda KP, Inglis A, Hampson J, Galambosi B, Asakawa Y. Biomass production, essential oil yield and composition of Myrica gale L. harvested from wild populations in Scotland and Finland. Flavour Frag J 1998; 13: 367-72.

[3] Huguet V, Gouy M, Normand P, Zimpfer JF, Fernandez MP. Molecular phylogeny of myricaceae: A reexamination of hostsymbiont specificity. Mol Phylogenet Evol 2005; 34: 557-68.

[4] Misirlioglu H, Stevens R, Meikle T. Synthesis of dihydrochalocones of Myrica gale. Phytochemistry 1978; 17: 2015-9.

[5] Carlton RR, Gary AI, Lavaud C, Massiot G, Waterman PG. Kaempferol-3-(2,3-Diacaetoxy-4-p-Coumaroyl) rhamonoside from leaves of Myrica Gale. Phytochemistry 1990; 29: 2369-71.

[6] Hamback PA, Agren J, Ericson L. Association resistance: insect damage to purple loosestrife reduced in thickets of sweet gale. Ecol 2000; 81: 1784-94.

[7] Santos SC, Waterman PG. Condensed tannins from Myrica gale, Fitoterapia 2000; 71: 610-2.

[8] Vaher M, Koel M. Separation of polyphenolic compounds extracted from plant matrices using capillary electrophoresis. J Chromatogr A 2003; 990: 225-30.
[9] Sylvestre M, Legault J, Dufour D, Pichette A. Chemical composition and anticancer activity of leaf essential oil of Myrica gale $L$. Phytomedicine 2005; 12: 299-304.

[10] Davey AJ, Gibson CM. Note on the distribution of sexes in Myrica gale. New Phytol1917; 16: 147-51.

[11] Crocker LJ, Schwintzer CR. Soil conditions affect the occurrence of cluster roots in Myrica Gale L. in the Field. Soil Biol Biochem 1994; 26: 615-22.

[12] Schwintzer CR, Lancelle SA. Effect of water-table on shoot growth, root growth, and nodulation of Myrica gale seeding. J Ecol 1983; 71, 489-501.

[13] Camp KV. Environmental variables that affect the establishment of Myrica gale seedlings, MSc Thesis, University of Maine, 2005

[14] Kuzyakov K, Friedel JK, Stahr K. Review of mechanisms and quantification of priming effects. Soil Biol Biochem 2000; 32: 1485-98.

[15] Martin P, Chang X. Development Sweet Gale (Mycica gale) as a new crop for the cosmetics industry. Aspect Appl Biol 2010; 101: $115-22$.

[16] Troelstra SR, Wagenaar R, Smant W. Growth of actinorhizal plants as influenced by the form of $\mathrm{N}$ with special reference to Myrica gale and Alnus incana. J Exp Bot 1992; 43: 1349-59.

Received: December 31, 2013

Revised: May 31, 2014

Accepted: June 27, 2014

(c) Chang and Martin; Licensee Bentham Open.

This is an open access article licensed under the terms of the Creative Commons Attribution Non-Commercial License (http://creativecommons.org/licenses/by-nc/3.0/) which permits unrestricted, non-commercial use, distribution and reproduction in any medium, provided the work is properly cited. 